Fifth International Conference on Sustainable Construction Materials and

Technologies. http://www.claisse.info/Proceedings.htm

\title{
A COMPARATIVE STUDY OF SITE-ADAPT AND ACI STANDARD DESIGN METHODS FOR STRUCTURAL DESIGN OF RC BUILDINGS IN KANDAHAR, AFGHANISTAN
}

\author{
Mohammad Numan Aloko ${ }^{1}$, \\ ${ }^{1}$ Department of Civil Engineering \\ Kandahar University, Kandahar City, Afghanistan. \\ Email address; numanaloko@kdru.edu.af, mohd.numan@hotmail.com.
}

\begin{abstract}
Design criteria for reinforced concrete structures consist of safety, economy, functionality, and aesthetic. Site-adapt or assumption method is a semiengineering practice for the designing of reinforced concrete structures in Kandahar, Afghanistan that relies on adapting earlier designed projects into the new ones. It is obvious that application of this approach influences safety and economy of constructions, therefore, consequences of site-adapt practice are studied through comparing it with ACI standard design method. A school building that had been designed by site-adapt method was selected as the case study and redesigned as per ACI 318M-11 code using STAAD PRO and STAAD RCDC software. Lastly, differentiating cost estimation of materials that show the variability due to the application of these two approaches by cost analysis. From the findings of the comparison, all the structural members that had been designed via site-adapt method resulted in overdesign condition. Other than that, the cost analysis of both approaches proved the costliness of the site-adapt design in which the increments in the expenses of the school building are $37 \%$ due to steel cost and $25 \%$ due to concrete.
\end{abstract}

Kevwords: Site-adapt method;structural analysis;concrete design;cost analysis

\section{INTRODUCTION}

Afghanistan is a developing country with rapid urbanization and population growth in which construction sector has a tremendous influence on the progress and infrastructure of the country. Housing is a massive need in all Afghanistan. Likewise, the demand for the residential homes, more schools, public buildings, health facilities, roads, irrigation canals are required for the enhancement of socio-economic conditions in Afghanistan. Currently, in Afghanistan, most of the new buildings are made of reinforced concrete. Ministry of Urban Development and Housing (MUDH) has the plan to build 185,175 residential units to fulfill the demand for housing need [1]. Furthermore, the private sector is investing in building small townships in the 
different urban areas. Consequently, there is a high consumption of reinforced concrete material for the constructing buildings in Afghanistan.

Despite great opportunities, there are some challenges for the construction sector in Afghanistan. These difficulties can be categorized into two groups as external and technical problems. The factors under the external group that have a negative impact on construction productivity are security, corruption, market inflation, augmentation of government regulations, and the Judicial system for construction disputes [2]. When comes to technical challenges, poor design, low availability of good quality materials, lack of qualified and skilled labor, the variety of construction standards and a short supply of fundamental engineering knowledge are the risks for the quality of the project's life cycle [3]. Afghan government approved the construction codes (Afghanistan Building Codes) that were prepared by Afghanistan National Standards Agency (ANSA) with the assistance of international professionals to enhance the situation for the construction sector and minimize the challenges in 2012. However, neither government institutions nor private construction companies passed to the implementation phase of these new regulations due to the codes have not been translated into local languages (Pashto and Dari) as international experts developed the codes in English and the unfamiliarity of the public and private sector to these engineering measures [4].

Initially, the system for construction project delivery was the design-build method in Afghanistan. Design-Build is a project delivery method in which one entity performs both design and construction services under a single contract [5]. Due to the unqualified construction companies, lack of technical capability, deficiency of skilled labor and management the design-build delivery method was difficult to implement [6]. Therefore, the site-adapt method has been used for most construction projects. Site-adapt approach implies that when government agencies or other organizations are requested to plan, analysis, and design a new project, they adapt and modify the past designed projects to the new site conditions without performing the complete process of design [3].

Despite the site-adapt method enhanced the construction process, some issues have been raised because of many projects were not regionally appropriate. This method also influenced the private construction sector and even some ministries. The main problem is that the complete process of load estimation, analyze and design of the new buildings are not conducted, just the design engineer in government agencies and consultancies taking an early designed project as a reference for the new project. For example, the sections of the structural elements and the area of reinforcement that are used in the previous projects are adjusted to the new project with some modifications without a complete load calculation and design. Usually, the engineer has a collection of past design projects when a design of a new project is requested, the design engineer searches for a similar previously designed project to use it as a source. 
This study aims to compare the site-adapt method with ACI standard design of reinforced concrete buildings using STAAD PRO software in Afghanistan by taking Kandahar which is the second largest city, as a case. Hence, an analytical study is needed to find the consequences of the site-adapt designed projects on safety and economy and to improve the analysis and design capacity of civil engineers in Kandahar, Afghanistan. Here, the study also purposes to show that design methods influence the sustainability of a structure in terms of economy and material usage.

\section{METHODOLOGY}

In this study, a school building which was designed by the site-adapt method has been redesigned according to ACI 318-011 code to explore the significant difference in costs and design of the structure. The site-adapt approach is applied for designing of most reinforced concrete buildings in Kandahar, Afghanistan. This practice involves adapting the model of the previous projects to the new ones, approximate calculation of reinforcement bars and little or no formal structural engineering inputs during design and construction processes. The present study was carried out in five stages to accomplish the objectives. The stages include obtaining the design documents from the contractor, estimation of loads according to ASCE 7-10, creating and analyzing of the model in STAAD PRO software, designing of the building using ACI 318-11 and cost analysis of the two types design methods.

\subsection{Selection of a Reinforced Concrete Building as a Case Study}

Various types of projects that are considered to be designed by site-adapt method were received from the consultants. The projects included three-story houses, school buildings, and public structures. Among them, the school building has been selected as the case study which was designed by Ministry of Education. The aim of selecting school building as a case study was the huge demand for the schools to be constructed in different parts of Afghanistan. The general specifications of the building have been summarized as below.

Table 2.1. General Specification of the Building

\begin{tabular}{|l|l|}
\hline Type of building & Reinforced Concrete \\
\hline Ground floor area & $421.62 \mathrm{~m}^{2}$ \\
\hline Number of stories & 2 \\
\hline Height of each story & $3 \mathrm{~m}$ \\
\hline $\begin{array}{l}\text { Compressive strength of concrete used for } \\
\text { slabs, beams, columns and foundation }\end{array}$ & C20 \\
\hline Steel reinforcement & Fy420 \\
\hline Partition walls & Brickwork \\
\hline Type of roof & $\begin{array}{l}\text { Timber truss covered by GI sheet } \\
\text { gauge 22 }\end{array}$ \\
\hline
\end{tabular}




\subsection{Load Estimation}

Two types of load have been taken into consideration: dead and live load. ASCE 710 standard (Minimum Design Loads for Buildings and Other Structures) was used for the specification of materials density and live load.

\subsection{Modeling and Analyzing of the Building Using STAAD PRO}

All the inputs for modeling and analyzing of the structure have been taken from the documents which were received from the constructor. Firstly the model was created in the STAAD PRO. Then, the estimated loads were applied to the structural elements and analyzed by STAAD PRO software. Section properties of the school building are presented in Table 2.2.

Table 2.2. Section Properties

\begin{tabular}{|l|c|l|}
\hline Member & $\begin{array}{l}\text { Dimensions } \\
(\mathrm{cm})\end{array}$ & Material \\
\hline Beams & $35 \times 40$ & Concrete \\
\hline Columns & $35 \times 35$ & Concrete \\
\hline Circular Columns & $\varnothing 35$ & Concrete \\
\hline Slab Thickness & $14 \mathrm{~cm}$ & Concrete \\
\hline
\end{tabular}

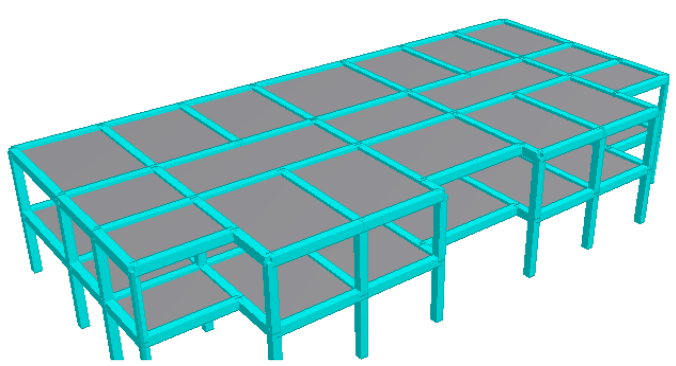

Figure 2.1: Model after Assigning of Section Properties

\subsection{Reinforced Concrete Designing of the Building}

All the structural members such as beams, columns, slabs, and foundations have been designed as per ACI $318 \mathrm{M}-11$ code using STAAD RCDC computer program. STAAD RCDC is an advanced concrete design software that is compatible with the STAAD PRO analytical program. It designs the concrete elements based on the analysis results of the STAAD PRO.

\subsection{Cost Analysis}

The cost analysis of two design method has been performed to determine the expenses contrast between them. This analysis was carried out in two conditions. The first condition compares just the steel weight used in the site-adapt and ACI standard methods because the section dimensions of concrete members have been maintained same as specified in the site-adapt. In other words, while calculating steel area for structural members in STAAD RCDC, same dimensions were used for beams, columns, and slabs to keep similarity with site-adapt designed members for investigating the state of overdesign or under design. However, in the second condition, the dimensions of reinforced concrete elements have been changed and redesigned in the STAAD RCDC. The second condition aims to show how concrete volume and steel can be decreased through accurate analysis and design of the building and to present the expenses difference of both concrete and steel material in the two methods. 
Table 2.3. Proposed Dimensions for Redesigning

\begin{tabular}{|l|c|}
\hline Structural Member & $\begin{array}{l}\text { Proposed Dimensions for Redesign Using ACI } \\
\text { Standard }\end{array}$ \\
\hline Beams ( Parallel with X axis) & $25 \mathrm{~cm} \mathrm{X} \mathrm{30} \mathrm{cm}$ \\
\hline Column (all) & $30 \mathrm{~cm} \mathrm{X} 30 \mathrm{~cm}$ \\
\hline Slabs (all) & $12.5 \mathrm{~cm}$ (Thickness) \\
\hline
\end{tabular}

Note: Dimensions of foundation is specified by software due to the bearing capacity of soil and loads of columns.

Table 2.4. Rates of Construction Materials in Afghanistan

\begin{tabular}{|l|l|}
\hline Unit of Material & Amount USD \\
\hline One bag $(50 \mathrm{Kg})$ of Portland Cement & $12 \$$ \\
\hline One cubic meter $\left(\mathrm{m}^{3}\right)$ of sand & $11 \$$ \\
\hline One cubic meter $\left(\mathrm{m}^{3}\right)$ of aggregates & $14 \$$ \\
\hline 2000 liter of Water & $15 \$$ \\
\hline One Ton $(1000 \mathrm{Kg})$ of Steel $(\mathrm{Uz}-\mathrm{Fy} 420)$ & $1200 \$$ \\
\hline
\end{tabular}

Note: These rates are changeable according to economic situations of the country. In this study, these rates are used just to compare the expenses contrast between two methods. The change in the rate of materials does not influence the difference of cost for these two methods.

Table 2.5. Estimation the Price of One Cubic Meter C20 Concrete Grade

\begin{tabular}{|l|l|}
\hline Material & Amount (USD) \\
\hline Rate of 8 bags of ordinary cement & $96 \$$ \\
\hline Rate of $0.415 \mathrm{~m}^{3}$ of sand & $4.57 \$$ \\
\hline Rate of $0.829 \mathrm{~m}^{3}$ aggregates & $11.61 \$$ \\
\hline Rate of 198 liter of water & $1.56 \$$ \\
\hline Total cost of one cubic C20 grade concrete & $113.74 \sim 115 \$$ \\
\hline
\end{tabular}




\section{RESULTS AND DISCUSSION}

\subsection{Comparison of Site-Adapt and ACI Standard Design Methods}

As stated earlier, the design documents of a school building have been obtained from the contractor that had been designed based on site-adapt method. The school building was redesigned as per ACI 318M-11 standard using STAAD RCDC. The results of the redesigned structural members such as beams, columns, slabs, and foundations have been compared with the sections which had been detailed by siteadapt method. All dimensions are in centimeters otherwise noted.

\subsubsection{Comparative Results of the Beams}

Two types of beams have been compared with each other. The first ones are the siteadapt designed beams, and the other ones are the ACI standard designed beams. The building consists of two floors; ground and first floor. The plans of both floors are the same. For the comparison, five critical beams in which maximum sagging and hogging moments occurred are selected in different frames. The calculated area of reinforcement for beams in both methods are showed in Table 3.1 through Table 3.4.

Table 3.1. Comparison of Reinforcement Area Provided for Sagging Moment in (Ground Floor).

\begin{tabular}{|c|c|c|c|}
\hline No & $\begin{array}{c}\text { Area }\left(\mathrm{mm}^{2}\right) \text { of } \\
\text { Reinforcement (Site- } \\
\text { Adapt Method) }\end{array}$ & $\begin{array}{c}\text { Area }\left(\mathrm{mm}^{2}\right) \text { of } \\
\text { Reinforcement (ACI } \\
\text { Standard Method) }\end{array}$ & $\begin{array}{c}\text { Difference of Two } \\
\text { Methods as percentage } \\
(\%)\end{array}$ \\
\hline $\mathbf{1}$ & 1256 & 679 & $46 \%$ \\
\hline $\mathbf{2}$ & 1256 & 679 & $46 \%$ \\
\hline $\mathbf{3}$ & 1256 & 566 & $55 \%$ \\
\hline $\mathbf{4}$ & 1017 & 452 & $56 \%$ \\
\hline $\mathbf{5}$ & 803 & 452 & $44 \%$ \\
\hline
\end{tabular}

Table 3.2. Comparison of Reinforcement Area Provided for Hogging Moment (Ground Floor).

\begin{tabular}{|c|c|c|c|}
\hline No & $\begin{array}{c}\text { Area }\left(\mathrm{mm}^{2}\right) \text { of } \\
\text { Reinforcement (Site- } \\
\text { Adapt Method) }\end{array}$ & $\begin{array}{c}\text { Area }\left(\mathrm{mm}^{2}\right) \text { of } \\
\text { Reinforcement (ACI } \\
\text { Standard Method) }\end{array}$ & $\begin{array}{c}\text { Difference of Two } \\
\text { Methods as percentage } \\
(\%)\end{array}$ \\
\hline $\mathbf{1}$ & 1570 & 1206 & $23 \%$ \\
\hline $\mathbf{2}$ & 1451 & 923 & $36 \%$ \\
\hline $\mathbf{3}$ & 1570 & 923 & $41 \%$ \\
\hline $\mathbf{4}$ & 1451 & 769 & $47 \%$ \\
\hline $\mathbf{5}$ & 1005 & 452 & $55 \%$ \\
\hline
\end{tabular}


Table 3.3. Comparison of Reinforcement Area Provided for Sagging Moment (First Floor).

\begin{tabular}{|c|c|c|c|}
\hline No & $\begin{array}{c}\text { Area }\left(\mathrm{mm}^{2}\right) \text { of } \\
\text { Reinforcement (Site- } \\
\text { Adapt Method) }\end{array}$ & $\begin{array}{c}\text { Area }\left(\mathrm{mm}^{2}\right) \text { of } \\
\text { Reinforcement (ACI } \\
\text { Standard Method) }\end{array}$ & $\begin{array}{c}\text { Difference of Two } \\
\text { Methods as percentage } \\
(\%)\end{array}$ \\
\hline 1 & 1017 & 452 & $56 \%$ \\
\hline 2 & 1017 & 452 & $56 \%$ \\
\hline 3 & 1017 & 452 & $56 \%$ \\
\hline 5 & 803 & 452 & $44 \%$ \\
\hline
\end{tabular}

Table 4.4. Comparison of Reinforcement Area Provided for Hogging Moment (First Floor).

\begin{tabular}{|c|c|c|c|}
\hline No & $\begin{array}{c}\text { Area }\left(\mathrm{mm}^{2}\right) \text { of } \\
\text { Reinforcement (Site- } \\
\text { Adapt Method) }\end{array}$ & $\begin{array}{c}\text { Area }\left(\mathrm{mm}^{2}\right) \text { of } \\
\text { Reinforcement (ACI } \\
\text { Standard Method) }\end{array}$ & $\begin{array}{c}\text { Difference of Two } \\
\text { Methods as percentage } \\
(\%)\end{array}$ \\
\hline $\mathbf{1}$ & 1017 & 769 & $24 \%$ \\
\hline $\mathbf{2}$ & 1165 & 566 & $51 \%$ \\
\hline $\mathbf{3}$ & 1017 & 452 & $56 \%$ \\
\hline $\mathbf{4}$ & 1005 & 452 & $55 \%$ \\
\hline $\mathbf{5}$ & 1005 & 452 & $55 \%$ \\
\hline
\end{tabular}

From Table 3.1 through Table 3.4, it can be seen that the steel area provided via the site-adapt method for sagging and hogging moments in two floors is exceeding almost over half or near to half of reinforcement as calculated by ACI method.

In the site-adapt approach, the same steel area which is needed for the beams with high internal forces is also provided for the members that they take smaller moments. However, in ACI standard method, all the beams are designed relevant to their internal forces as per the result of the analysis. When it comes to shear design, there was no significant difference between steel areas provided by both methods. The spacing of stirrups and the size of rebar are nearly the same in both designs.

\subsubsection{Comparative Results of the Columns}

In design documents that were received from contractor just four types of sections had been designed for columns. Table 3.5 and Table 3.6 compares the results of software design for columns with the sections defined by the site-adapt method. 
Table 3.5. Comparison of Columns' Sections in the Ground Floor

\begin{tabular}{|c|c|c|c|}
\hline No & $\begin{array}{c}\text { Area }\left(\mathrm{mm}^{2}\right) \text { of } \\
\text { Reinforcement (Site- } \\
\text { Adapt Method) }\end{array}$ & $\begin{array}{c}\text { Area }\left(\mathrm{mm}^{2}\right) \text { of } \\
\text { Reinforcement (ACI } \\
\text { Standard Method) }\end{array}$ & $\begin{array}{c}\text { Difference of Two Methods } \\
\text { as percentage (\%) }\end{array}$ \\
\hline $\mathbf{1}$ & 3799 & 1231 & $67.6 \%$ \\
\hline $\mathbf{2}$ & 3404 & 1206 & $64.6 \%$ \\
\hline $\mathbf{3}$ & 3404 & 1231 & $63.8 \%$ \\
\hline
\end{tabular}

Table 3.6. Comparison of Columns' Sections in the First Floor

\begin{tabular}{|c|c|c|c|}
\hline No & $\begin{array}{c}\text { Area }\left(\mathrm{mm}^{2}\right) \text { of } \\
\text { Reinforcement (Site- } \\
\text { Adapt Method) }\end{array}$ & $\begin{array}{c}\text { Area }\left(\mathrm{mm}^{2}\right) \text { of } \\
\text { Reinforcement (ACI } \\
\text { Standard Method) }\end{array}$ & $\begin{array}{c}\text { Difference of Two Methods } \\
\text { as percentage (\%) }\end{array}$ \\
\hline 1 & 3140 & 1231 & $61 \%$ \\
\hline 2 & 2035 & 1206 & $41 \%$ \\
\hline 4 & 2543 & 1231 & $52 \%$ \\
\hline
\end{tabular}

Based on Tables 3.5 and 3.6, there is a significant difference between the steel areas provided by both design methods for columns of the structure. The steel area designed via ACI method is around 50\% less than the area provided through the siteadapt approach. No important differences were found between the types of links and their spacing in two methods.

\subsubsection{Comparison of the Slabs}

There are eighteen slabs on the ground floor. Five slabs are selected for comparison of two methods because other slabs are similar in size and load conditions. In siteadapt and ACI design methods, for the slabs of both levels, same steel area is provided. Thus, the comparison was carried out only for the ground floor. Table 3.7 shows the properties of slabs.

Table 3.7. Properties of Selected Slabs for Comparison

\begin{tabular}{|c|c|c|c|c|}
\hline NO & Slab Mark & $\mathbf{L x}(\mathbf{m})$ & $\mathbf{L y}(\mathbf{m})$ & Span Type \\
\hline $\mathbf{1}$ & S1 & 3.93 & 5.35 & Two Way \\
\hline $\mathbf{2}$ & S7 & 3.35 & 3.93 & Two Way \\
\hline $\mathbf{3}$ & S8 & 3.35 & 7.86 & One Way \\
\hline $\mathbf{4}$ & S9 & 3.35 & 5.55 & Two Way \\
\hline
\end{tabular}




\begin{tabular}{|l|l|l|l|l|}
\hline $\mathbf{5}$ & $\mathrm{S} 14$ & 4.30 & 5.55 & Two Way \\
\hline
\end{tabular}

Five slabs were compared to find the difference of steel area per meter of the short and long span. Table 3.8 and Table 3.9 illustrate the difference between steel area per meter of these slabs designed via site-adapt and ACI standard method. Due to Table 3.8 , for the short spans of the slabs, the difference is around $25 \%$ which means more $228 \mathrm{~mm}^{2} / \mathrm{m}$ of steel is provided through site-adapt approach than ACI standard method. In other words, in every meter of short span, there are additional $228 \mathrm{~mm}^{2}$ of steel in the design of site-adapt method. According to Table 3.9 for long-span, the slabs S1, S8, and S14 are also like in the short span have more steel than the standard design. However, the reinforcement for slab S9 is same in both methods, and for the S7, the difference is negative that means the $94 \mathrm{~mm}^{2} / \mathrm{m}$ of steel in the ACI method is more than the other one. This variation is small and can be accepted as insignificant. Finally, the overall contrast is $25 \%$ between the steel areas which were designed by two methods.

Table 3.8. Comparison of Steel Areas Provided by both Methods

\begin{tabular}{|c|c|c|c|}
\hline \multirow{2}{*}{ NO } & Site-Adapt & ACI Standard & Difference (\%) \\
\cline { 2 - 3 } & $\left(\mathrm{mm}^{2} / \mathrm{m}\right)$ of Short Span & $\left(\mathrm{mm}^{2} / \mathrm{m}\right)$ of Short Span & \\
\hline $\mathbf{2}$ & 942 & 714 & $24 \%$ \\
\hline $\mathbf{3}$ & 952 & 714 & $25 \%$ \\
\hline $\mathbf{4}$ & 910 & 714 & $22 \%$ \\
\hline $\mathbf{5}$ & 936 & 714 & $24 \%$ \\
\hline
\end{tabular}

Table 3.9. Comparison of Steel Areas Provided by both Methods

\begin{tabular}{|c|c|c|c|}
\hline \multirow{2}{*}{ NO } & Site-Adapt & ACI Standard & Difference (\%) \\
\cline { 2 - 3 } & $\left(\mathrm{mm}^{2} / \mathrm{m}\right)$ of Long Span & $\left(\mathrm{mm}^{2} / \mathrm{m}\right)$ of Long Span & \\
\hline $\mathbf{1}$ & 951 & 714 & $25 \%$ \\
\hline $\mathbf{2}$ & 620 & 714 & $-15 \%$ \\
\hline $\mathbf{3}$ & 314 & 252 & $20 \%$ \\
\hline $\mathbf{5}$ & 714 & 714 & $0 \%$ \\
\hline
\end{tabular}

\subsubsection{Design Comparison of the Foundations}

Four types of isolated foundations had been designed for the columns of the structure through the site-adapt method. These four kinds of footings have been compared with the supports that were redesigned by ACI standard using STAAD RCDC. For the redesigning, the values of safe bearing capacity and density of soil have been 
taken from the geotechnical report of soil investigation that was obtained from the contractor responsible for material testing. In the geotechnical report, $96 \mathrm{KPa}$ $\left(\mathrm{KN} / \mathrm{m}^{2}\right)$ is recommended for the safe bearing capacity of the soil, and the maximum dry density of soil is found: $20.62 \mathrm{KN} / \mathrm{m}^{3}$.

According to Table 3.10 and Table 3.11, the design results of STAAD RCDC for the foundations F1, F2 show similarity with the site-adapt method. However, the difference for the F3 and F4 is $24 \%$ and $44 \%$ respectively. The length and width of the foundations also vary $15 \mathrm{~cm}$ to $20 \mathrm{~cm}$ in two methods. This is may be due to some assumptions and design inputs in the software. Consequently, the size and steel area of the F3 have considerable influence on the cost of the building because 18 columns have the F3 type footing. Although the difference for the F4 is the highest among other types, only two columns have F4 type support. Therefore, it has less impact on the overall cost of the foundation

Table 3.10. Comparison of Foundations

\begin{tabular}{|c|c|c|c|}
\hline \multirow{2}{*}{ No } & Site-Adapt Method & ACI Standard & Difference (\%) \\
\cline { 2 - 3 } & $\begin{array}{c}\text { Area }\left(\mathrm{mm}^{2}\right) \text { of Steel at the } \\
\text { long side }(\mathrm{L})\end{array}$ & $\begin{array}{c}\text { Area }\left(\mathrm{mm}^{2}\right) \text { of Steel at the } \\
\text { long side }(\mathrm{L})\end{array}$ & \\
\hline $\mathbf{1}$ & 1696 & 1544 & $9 \%$ \\
\hline $\mathbf{2}$ & 1583 & 1449 & $8 \%$ \\
\hline $\mathbf{3}$ & 1470 & 1197 & $24 \%$ \\
\hline $\mathbf{4}$ & 1243 & 693 & $44 \%$ \\
\hline
\end{tabular}

Table 3.11. Comparison of Foundations

\begin{tabular}{|c|c|c|c|}
\hline \multirow{2}{*}{ No } & Site-Adapt Method & ACI Standard & Difference (\%) \\
\cline { 2 - 3 } & $\begin{array}{c}\text { Area }\left(\mathrm{mm}^{2}\right) \text { of Steel at the } \\
\text { Width }(\text { B })\end{array}$ & $\begin{array}{c}\text { Area }\left(\mathrm{mm}^{2}\right) \text { of Steel at the } \\
\text { Width }(B)\end{array}$ & \\
\hline $\mathbf{1}$ & 1696 & 1544 & $9 \%$ \\
\hline $\mathbf{2}$ & 1583 & 1449 & $8 \%$ \\
\hline $\mathbf{3}$ & 1583 & 1197 & $25 \%$ \\
\hline $\mathbf{4}$ & 1243 & 693 & $44 \%$ \\
\hline
\end{tabular}

\subsection{Results of Cost Analysis}

Cost analysis for both conditions have been performed, and the results are revealed in the following tables and figures. In both situations, the results show that the sections that were designed by ACI standard method cost much lower than the price of materials that had been defined using site-adapt approach. 


\subsubsection{Results of Cost Analysis for First Condition}

Figure 3.1 compares the steel weight that was used in both methods. As it can be seen from the results, the higher quantity of steel used in the site-adapt approach than ACI Standard. This is due to the inappropriate estimation of nominal design loads and inaccurate analysis and design of structural elements. Furthermore, this situation also has the impact on the overall construction expenses of the building. For instance, the costs of total steel weight that were used in two methods are compared in Figure 3.2. The difference is $39 \%$.

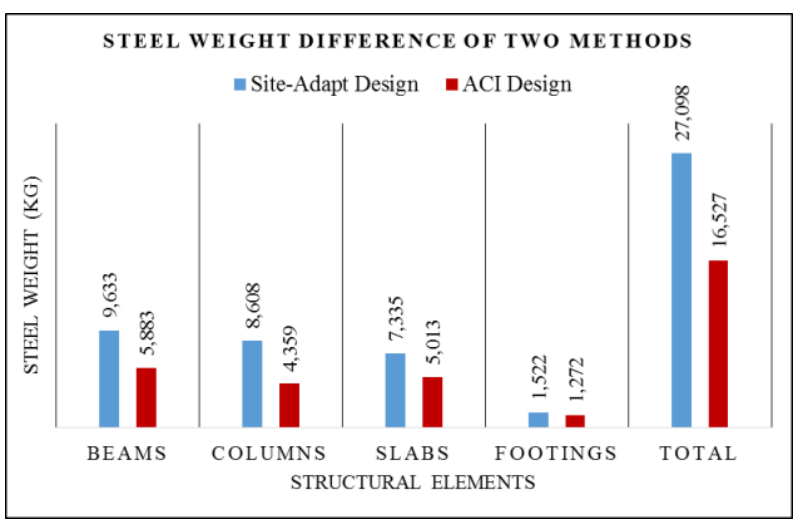

Figure 3.1: Steel Weight Difference of Two Methods

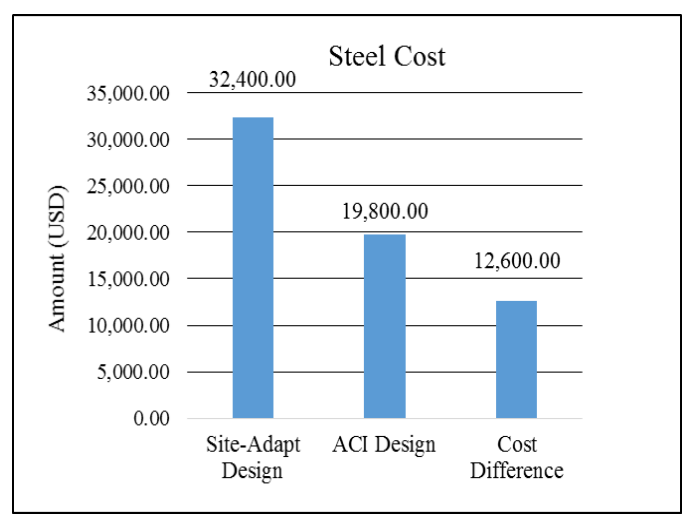

Figure 3.2: Cost Difference of Steel Used in Two Methods

Consequently, for this building that had been designed through site-adapt method, $10,571 \mathrm{~kg}$ (10.5 ton) of steel that costs $12,600 \$$ was used additionally than the reinforcement provided by ACI standard design.

\subsubsection{Results of Cost Analysis for Second Condition}

In the previous part, only steel weight was compared because the dimensions of structural members were kept similar as the site-adapt designed sizes. However, in this section, besides steel weight, the concrete volume is also considered due to the changes in the dimensions of beams, columns, slabs, and footings. For steel weight comparison, the result is almost like as in the earlier part. When it comes to concrete volume, the site-adapt designed building members require more 53 cubic meters of concrete than the ACI defined members. These variations are illustrated in Figures 3.3 and 3.4 respectively.

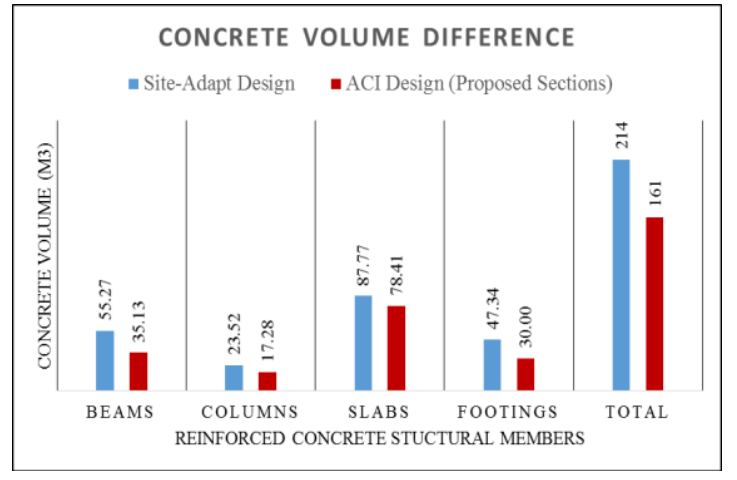

Figure 3.3: Concrete Volume Difference

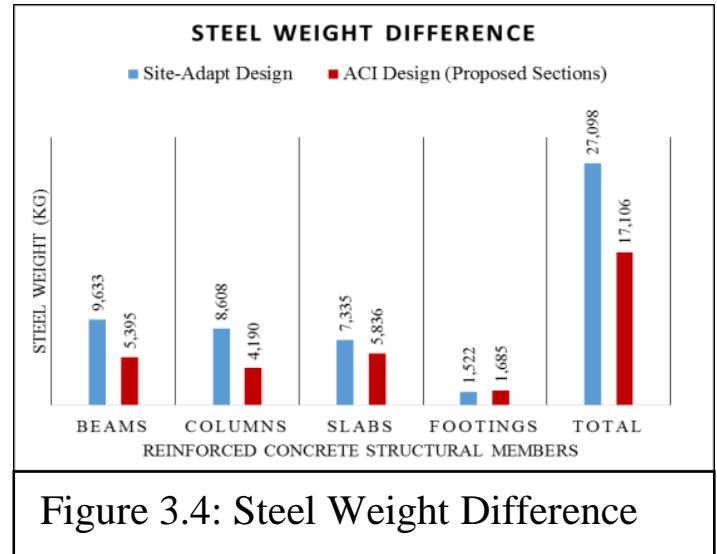


According to Figure 3.3 and 3.4, the expenses amounts which can be saved by applying ACI design are $37 \%$ in steel and $25 \%$ in concrete. As the consequence of practicing site-adapt or assumption method, 10 ton of steel and $53 \mathrm{~m}^{3}$ of concrete that costs around $18000 \$$ were consumed in excess quantity.

\section{CONCLUSION}

The site-adapt approach that is used by some civil engineers for the designing of concrete structures in Kandahar, Afghanistan has been compared with ACI standard design to check the condition of overdesign and under design. Finally, cost estimation of materials that show the variability due to the application of site-adapt and ACI standard design methods have been carried out by cost analysis.

The conclusions of this study can be drawn as follow:

- From the findings of the comparison between site-adapt and ACI design methods using same geometrical and material properties, in terms of the same loading conditions, all the structural members such as beams, columns, slabs, and footings that had been designed via site-adapt method resulted in overdesign condition. This is due to the inappropriate estimation of nominal design loads and inaccurate analysis and design of structural elements.

- As the consequence of practicing site-adapt or assumption method, 10 ton of steel and $53 \mathrm{~m}^{3}$ of concrete were consumed in excess quantity in the construction of the school building.

- The cost analysis of the school building that was conducted for both methods proved the costliness of the site-adapt method. The increments in the expenses are $37 \%$ due to steel cost and $25 \%$ due to concrete.

- The site-adapt approach is not sustainable structural design as it was compared to ACI method due to usage of excess amount materials.

\section{REFERENCES}

[1] UN-Habitat., \& Ministry of Urban Development and Housing.(2017). Afghanistan Housing Profile.

[2] Gidado, K., \& Karimi, S. (2012). Factors influencing construction productivity in Afghanistan.

[3] Affleck, R., Seman, P., Deegan, M., Freeman, R., \& Sargand, S. (2011). Documenting lessons learned in Afghanistan concerning design and construction challenges (No. ERDC/CRREL-TR-11-02). ). Engineer Research and Development Center Hanover NH Cold Regions Research and Engineering Lab.

[4] Haziq, D., \& Kiyotaka, M. (2017) Afghanistan Building Codes (ABC): Focused on Comparative Analysis and the Viability of Enforcement. In AEI 2017 (pp. 138-149). 
[5] DBIA. (n.d.) Design-Build Instituion of America. Retrieved October 30, 2017, from https://www.dbia.org/about/Pages/What-is-Design-Build.aspx

[6] Affleck, R. T., \& Freeman, R. (2010). Challenges for engineering design, construction, and maintenance of infrastructure in Afghanistan (No. ERDC/CRREL-SR-10-2). Engineer Research and Development Center Hanover NH Cold Regions Research and Engineering Lab. 